\title{
The Effect of Temperature on the Solar Cell Efficiency, Output Currents and Voltages
}

\author{
Asim Ahmed Mohamed Fadol ${ }^{1}$, Mohammed M. Rashed ${ }^{2}$, L. M. Abdalgadir ${ }^{2} \&$ Essam E. Ali $^{3}$ \\ ${ }^{1}$ Department of Physics, College of Applied and Industrial Science, \& Comboni College of Science \& \\ Technology, University of Bahri, Khartoum, Sudan \\ ${ }^{2}$ Department of Physics, College of Science and Humanities at Hurrymilla, Shaqra University, Saudi Arabia \\ ${ }^{3}$ Department of Physics, University College of Turbah, Taif University, Taif, Saudi Arabia \\ Correspondence: Essam E. Ali, Department of Physics, University College of Turbah, Taif University, P.O. Box \\ 11099, Taif 21944, Saudi Arabia. E-mail: e.elgeily@tu.edu.sa
}

Received: May 17, 2021

Accepted: July 31, 2021

Online Published: November 9, 2021

doi:10.5539/apr.v13n2p55

URL: https://doi.org/10.5539/apr.v13n2p55

\begin{abstract}
Experimental results shows that all electrical parameters of solar cell such as maximum output power, open circuit voltage, short circuit current, and fill factor beside efficiency have been changed with temperature. According to results, the most significant is the temperature dependence of the voltage which decreases with increasing temperature while the current of cells slightly increases by temperature. The fill factor and the efficiency decrease upon increasing temperature. This confirms the fact that the voltage decrease is more significant than the current increase.
\end{abstract}

Keywords: maximum output power, open circuit voltage, solar cell, fill fact, temperature

\section{Introduction}

Solar energy is inexhaustible renewable energy for humans. It's also clean energy; do not generate any environmental pollution (Li, B., Wang, L., Kang, B., \& Qiu, Y., 2006). Solar photovoltaic was the most watched item in the researching of solar energy utilize. The PV solar power represents one of the most promising renewable energy in the world (Würfel, P., 2005; Kamat, P. V., et al., 2010). There are different types of PV cells which make solar modules: crystalline silicon, multi-crystalline, mono-crystalline, amorphous silicon etc. (Sattlerm, D., 2011; Markoff, 2007). PV technology is well-proven for producing electricity (Vidal, J., 2007). PV systems can be either grid connected (with electricity fed directly into the grid system) or PV systems used in off-grid applications in small power systems in combination with diesel power gen-sets (Green, M. A., 2006; Fang, J., Su, L., Wu, J., Shen, Y., \&. Lu, Z., 2007). Solar PV technology is especially suitable for electricity generation in off-grid power plants in rural desert areas and the use of solar energy in such hybrid systems can reduce diesel fuel use (Shockley, W., \& Queisser, H. J., 1961). The output of PV is rated by manufacturers under Standard Test Conditions (STC), temperature $=25 \mathrm{C}^{\mathrm{O}}$; solar irradiance (intensity) $=1000 \mathrm{~W} / \mathrm{m}^{2}$, and solar spectrum as filtered by passing through 1.5 thickness of atmosphere. These conditions are easily recreated in a factory, but the situation is different for outdoor (Brown, S., \& Green, M. A., 2002; Green, M. A., 2011). With the increasing use of PV systems, it is vital to know what effect active meteorological parameters such as humidity, dust, temperature, wind speed; etc. has on its efficiency (Schmidt, W., Woesten, B., \& Kalejs, J. P., 2002). In hot countries the performance of solar cells will be affected by temperature. This may include open circuit voltage, short circuit current, fill factor and efficiency (Sze, S. M., 1985; Braun, A., Katz, E. A., \& Gordon, J. M., 2012). This effect was verified and recorded in section (3). Sections 2, 3, 4 and 5 are devoted for materials beside methods, results, discussion and conclusion.

\section{Experimental Methods}

Solar cell properties can be altered by changes in environmental conditions such as temperature. Typically, solar cells are used at the temperature range between 5 to $50^{\circ} \mathrm{c}$. In this paper, temperature dependence of solar cells electric on parameters such as open circuit voltage, fill factor, short circuit current and efficiency is investigated. Experiments were conducted on solar panels with a constant-power light source, to determine the resulting electrical power generated and efficiency, beside performance. 


\subsection{Equipment's}

The following equipment was used in this experiment: poly-crystalline - Si solar cell was illuminated by lamp with light intensity equal to 100 watt/ $\mathrm{m}^{2}$. The electrical parameters of the PV cell were evaluated using digital multimeter measuring DC current and for DC voltage. A series of reading of $\mathrm{V}$ and was found by changing source resistant. Thermometer was used in order to measure the cell temperature.

Table 1. The specification of solar cell in which measurement was made under stander test condition (STC)

\begin{tabular}{cccccccc}
\hline$p_{m}($ watt $)$ & $\mathrm{V}(\mathrm{V})$ & $I_{m}(\mathrm{~A})$ & $V_{o c}($ volt $)$ & $I_{s c}(\mathrm{~A})$ & $\operatorname{Size}(\mathrm{mm})$ & Weight $(\mathrm{kg})$ & $\operatorname{Area}\left(\mathrm{m}^{2}\right)$ \\
\hline 3 & 9 & 0.33 & 11.2 & 0.37 & $20 * 180 * 17$ & 0.5 & 0.022 \\
\hline
\end{tabular}

\section{Results}

The measurements were performed at $(25,30,35,40,45,50$ and 55$) \mathrm{C}^{\mathrm{O}}$ by highly accurate measuring equipment's. To changed temperature one used control room with air condition to carry out experiment under constant ambient temperature and heat, one used electric heater. The distance between the lamp and the solar cell $0.35 \mathrm{~m}$. A series of reading $\mathrm{V}$ and $\mathrm{I}$ need to be found by changing source resistant. Form V-I curve, $I_{s c}, V_{o c}, V_{m}, I_{m}$ were founded. The efficiency $\eta$, fill factor FF and $p_{\max }$ beside energy gap $E_{g}$ should be found using the equations.

$$
\begin{gathered}
K T \sim 10^{-23} \times 10^{2} \sim 10^{-21} \\
E_{g} \sim 1 \times 1.6 \times 10^{-19} \sim 10^{-19} \\
\frac{E_{g}}{K T} \sim \frac{10^{-19}}{10^{-21}} \sim 100 \\
I_{o}=1.5 \times 10^{5} e^{\frac{-E g}{K T}}=15 \times 10^{4} e^{-100} \\
I_{o}=\frac{15 \times 10^{4}}{e^{100}}
\end{gathered}
$$

Table 2. I-V characteristic of solar cell at $25 \mathrm{C}^{\mathrm{O}}$ temperature

\begin{tabular}{cccccccccccc}
\hline $\mathrm{R} \times 10^{3} \Omega$ & 0 & 1 & 2 & 3 & 4 & 5 & 6 & 7 & 8 & 9 & 10 \\
\hline$V_{o c}($ volt $)$ & 0.023 & 7 & 7.6 & 8.08 & 8.24 & 8.32 & 8.36 & 8.4 & 8.47 & 8.5 & 8.5 \\
\hline$I_{s c}(\mathrm{~m} \mathrm{~A})$ & 10.49 & 9.2 & 7.2 & 3.9 & 2.6 & 2 & 1.6 & 1.3 & 0.88 & 0.7 & 0.61 \\
\hline
\end{tabular}

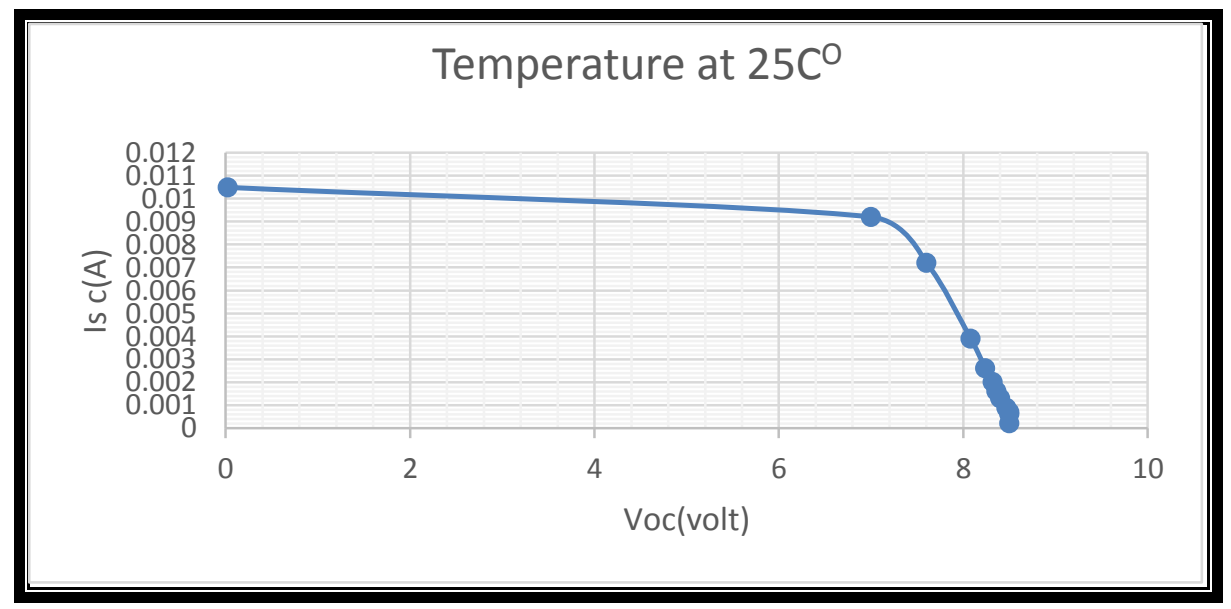

Figure $1 . \mathrm{I}-\mathrm{V}$ characteristics of solar cell for at $25 \mathrm{C}^{\mathrm{O}}$ temperature 
Table 3. I-V characteristics of solar cell at $30 \mathrm{C}^{\mathrm{O}}$ temperature

\begin{tabular}{cccccccccccc}
\hline $\mathrm{R} \times 10^{3} \Omega$ & 0 & 1 & 2 & 3 & 4 & 5 & 6 & 7 & 8 & 9 & 10 \\
\hline$V_{o c}$ (volt) & 0.02 & 6.8 & 7.38 & 7.97 & 8.02 & 8.19 & 8.24 & 8.27 & 8.28 & 8.29 & 8.32 \\
\hline$I_{s c}(\mathrm{~m} \mathrm{~A})$ & 10.6 & 9.3 & 7.38 & 4.04 & 2.75 & 2.08 & 1.68 & 1.42 & 1.03 & 0.85 & 0.76 \\
\hline
\end{tabular}

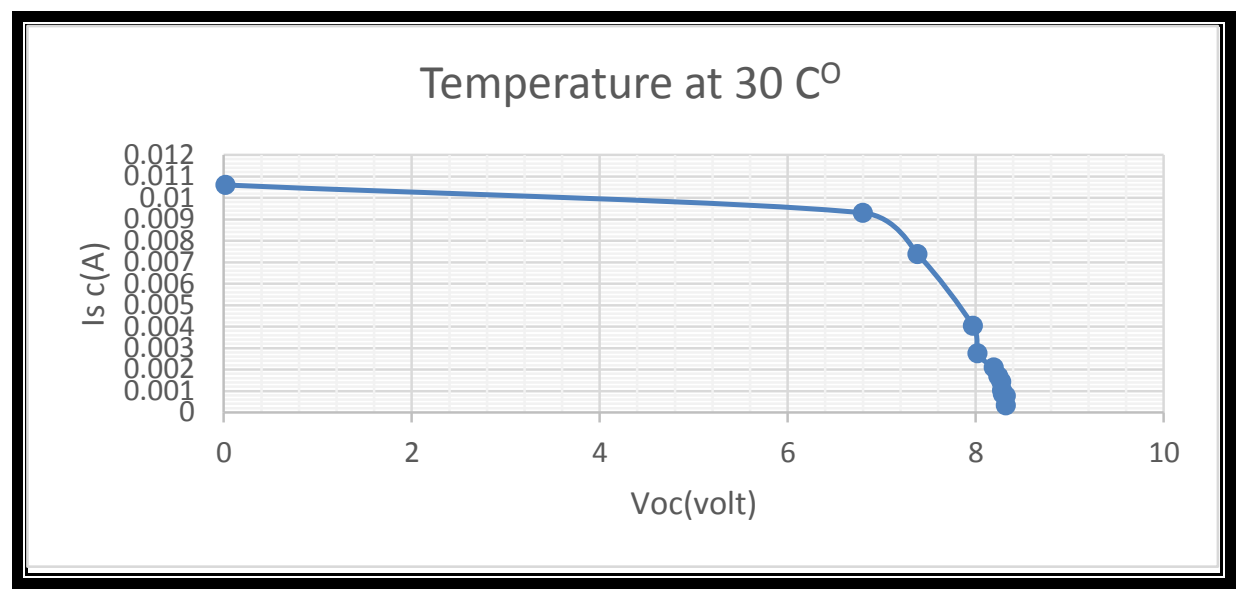

Figure 2. I-V characteristics of solar cell for temperature at $30 \mathrm{C}^{\mathrm{O}}$

Table 4. I-V characteristics of solar cell at $35 \mathrm{C}^{\mathrm{O}}$ temperature

\begin{tabular}{rrrrrrrrrrrr}
\hline $\mathrm{R} \times 10^{3} \Omega$ & $\mathrm{O}$ & 1 & 2 & 3 & 4 & 5 & 6 & 7 & 8 & 9 & 10 \\
\hline$V_{o c}($ volt $)$ & 0.016 & 6.7 & 7.21 & 7.75 & 7.9 & 8.01 & 8.15 & 8.2 & 8.27 & 8.28 & 8.3 \\
\hline$I_{s c}(\mathrm{~m} \mathrm{~A})$ & 10.75 & 9.4 & 7.39 & 4.19 & 2.9 & 2.25 & 1.69 & 1.5 & 1.18 & 1.03 & 0.82 \\
\hline
\end{tabular}

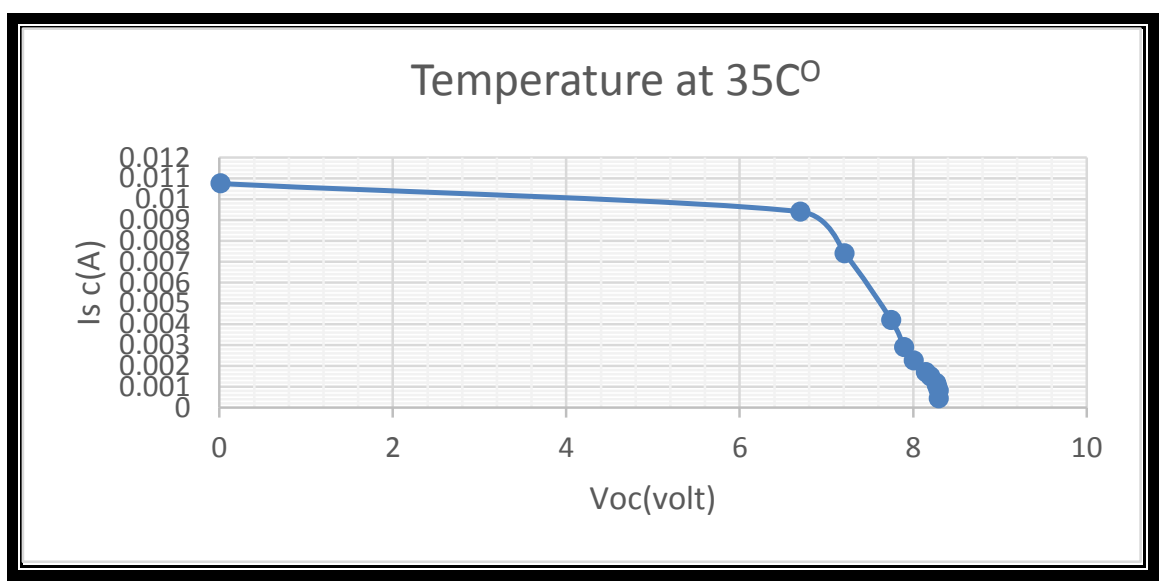

Figure 3. I-V characteristics of solar cell at $35 \mathrm{C}^{\mathrm{O}}$ temperature

Table 5. I-V characteristics of solar cell at $40 \mathrm{C}^{\mathrm{O}}$ temperature

\begin{tabular}{cccccccccccc}
\hline $\mathrm{R} \times 10^{3} \Omega$ & $\mathrm{O}$ & 1 & 2 & 3 & 4 & 5 & 6 & 7 & 8 & 9 & 10 \\
\hline$V_{o c}$ (volt) & 0.015 & 6.5 & 7.19 & 7.6 & 7.7 & 7.8 & 8.05 & 8.12 & 8.15 & 8.15 & 8.15 \\
\hline$I_{s c}(\mathrm{~m} \mathrm{~A})$ & 10.9 & 9.5 & 7.4 & 4.34 & 3.04 & 2.5 & 1.84 & 1.63 & 1.4 & 1.25 & 0.97 \\
\hline
\end{tabular}




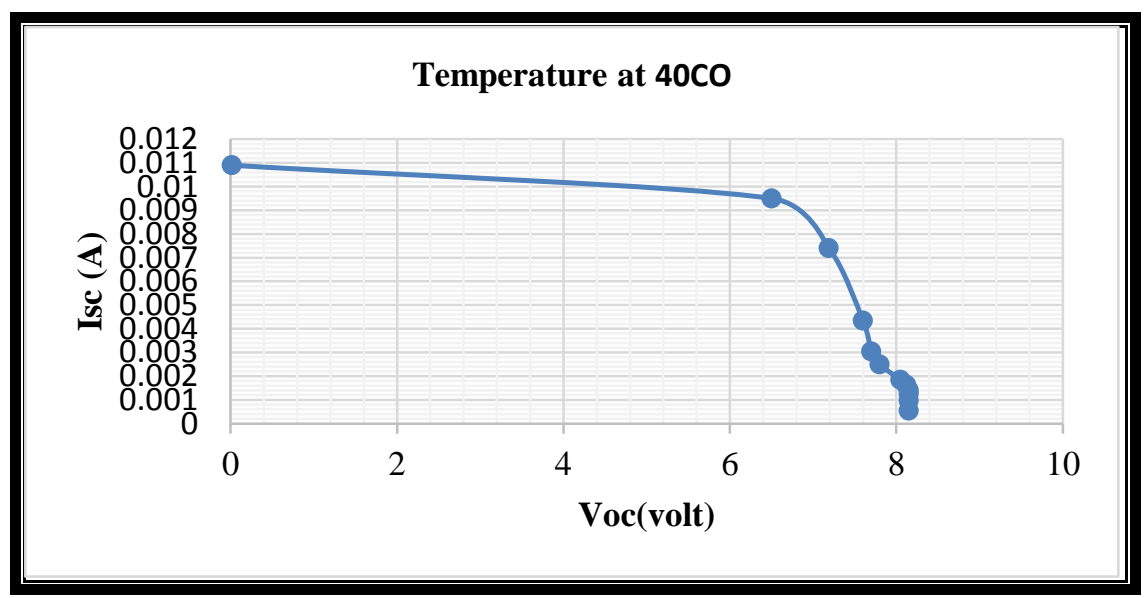

Figure 4. I-V characteristics of solar cell at $40 \mathrm{C}^{\mathrm{O}}$ temperature

Table 6. I-V characteristics of solar cell at $45 \mathrm{C}^{\mathrm{O}}$ temperature

\begin{tabular}{cccccccccccc}
\hline $\mathrm{R} \times 10^{3} \Omega$ & $\mathrm{O}$ & 1 & 2 & 3 & 4 & 5 & 6 & 7 & 8 & 9 & 10 \\
\hline$V_{o c}($ volt $)$ & 0.0149 & 6.3 & 7 & 7.5 & 7.69 & 7.72 & 7.95 & 8 & 8.07 & 8.07 & 8.07 \\
\hline$I_{s c}(\mathrm{~m} \mathrm{~A})$ & 10.95 & 9.65 & 7.42 & 4.4 & 3.19 & 2.66 & 1.87 & 1.77 & 1.55 & 1.5 & 1.2 \\
\hline
\end{tabular}

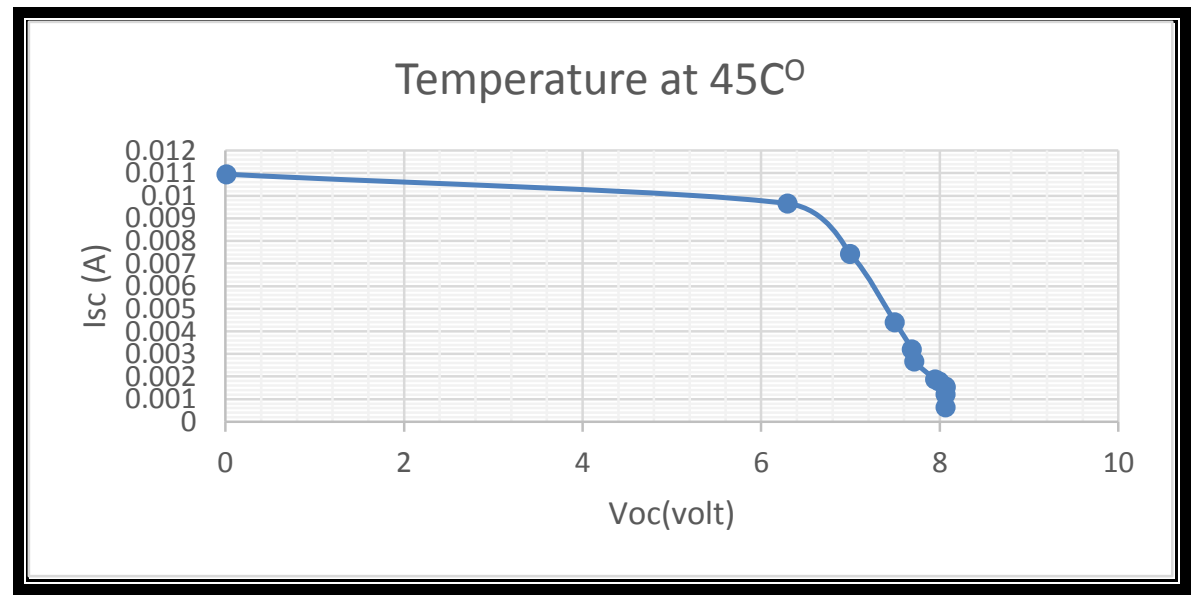

Figure 5. I-V characteristics of solar cell at $45 \mathrm{C}^{\mathrm{O}}$ temperature

Table 7. I-V characteristics of solar cell at $50 \mathrm{C}^{\mathrm{O}}$ temperature

\begin{tabular}{cccccccccccc}
\hline $\mathrm{R} \times 10^{3} \Omega$ & $\mathrm{O}$ & 1 & 2 & 3 & 4 & 5 & 6 & 7 & 8 & 9 & 10 \\
\hline$V_{o c}$ (volt) & 0.0148 & 6.1 & 6.9 & 7.39 & 7.5 & 7.6 & 7.8 & 7.95 & 8.02 & 8.02 & 8.02 \\
\hline$I_{s c}$ (m A) & 11.12 & 9.73 & 7.45 & 4.62 & 3.25 & 2.8 & 1.99 & 1.8 & 1.69 & 1.62 & 1.25 \\
\hline
\end{tabular}




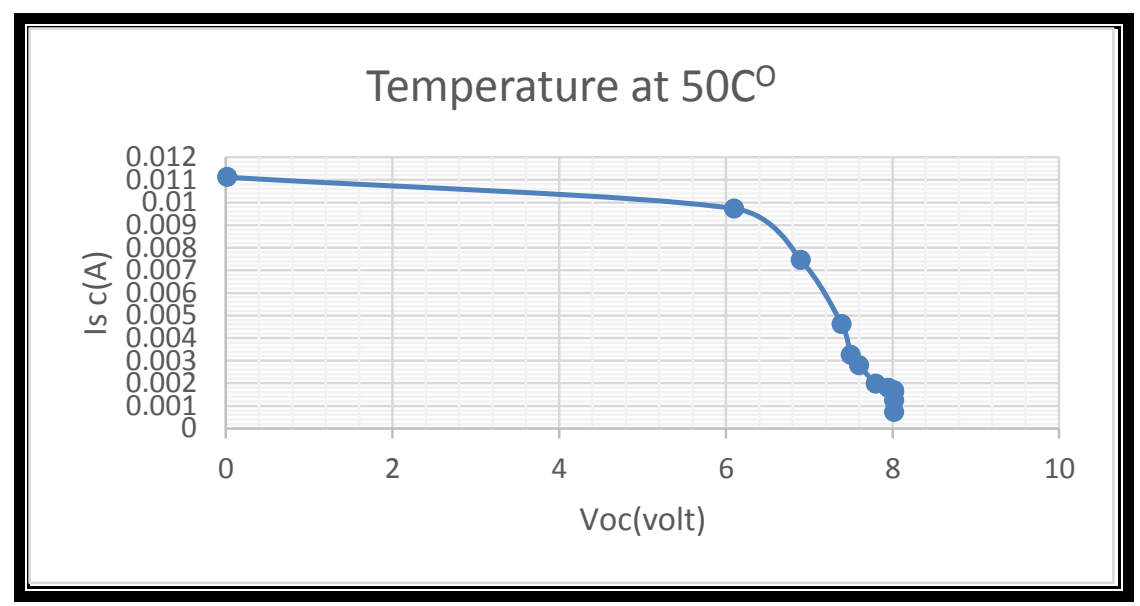

Figure 6. I-V characteristics of solar cell at $50 \mathrm{C}^{\mathrm{O}}$ temperature

Table 8. I-V characteristics of solar cell at $55 \mathrm{C}^{\mathrm{O}}$ temperature

\begin{tabular}{cccccccccccc}
\hline $\mathrm{R} \times 10^{3} \Omega$ & $\mathrm{O}$ & 1 & 2 & 3 & 4 & 5 & 6 & 7 & 8 & 9 & 10 \\
\hline$V_{o c}($ volt $)$ & 0.0139 & 5.9 & 6.7 & 7.23 & 7.46 & 7.69 & 7.89 & 7.89 & 7.89 & 7.89 & 7.89 \\
\hline$I_{s c}(\mathrm{~m} \mathrm{~A})$ & 11.2 & 10 & 7.47 & 4.78 & 3.5 & 2.9 & 2.03 & 1.97 & 1.72 & 1.66 & 1.3 \\
\hline
\end{tabular}

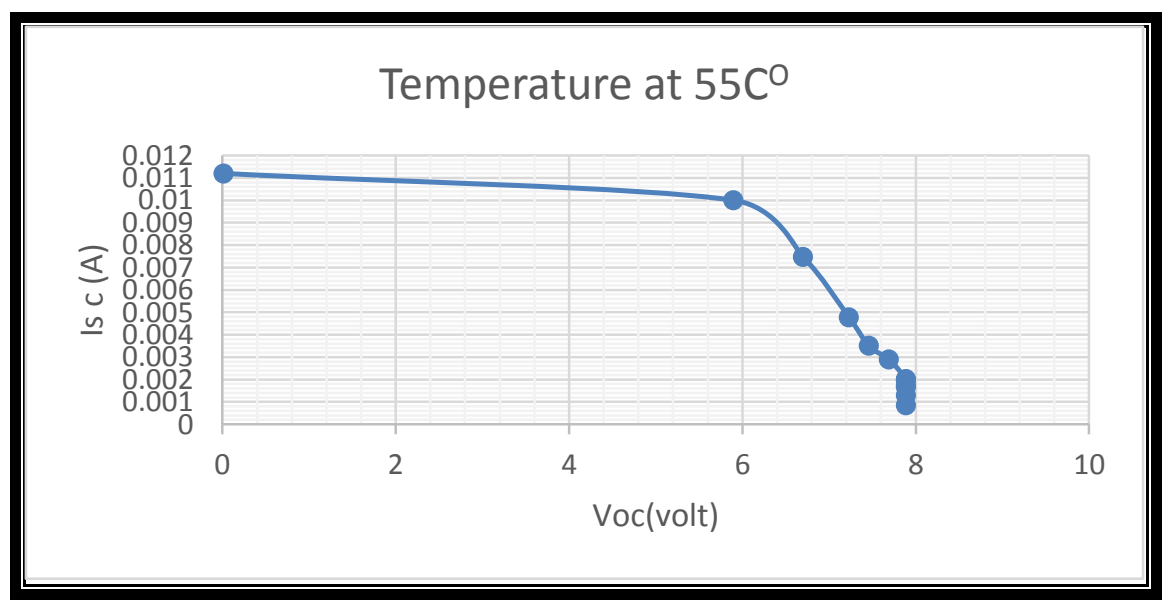

Figure 7. I-V characteristics of solar cell at $55 \mathrm{C}^{\mathrm{O}}$ temperature 


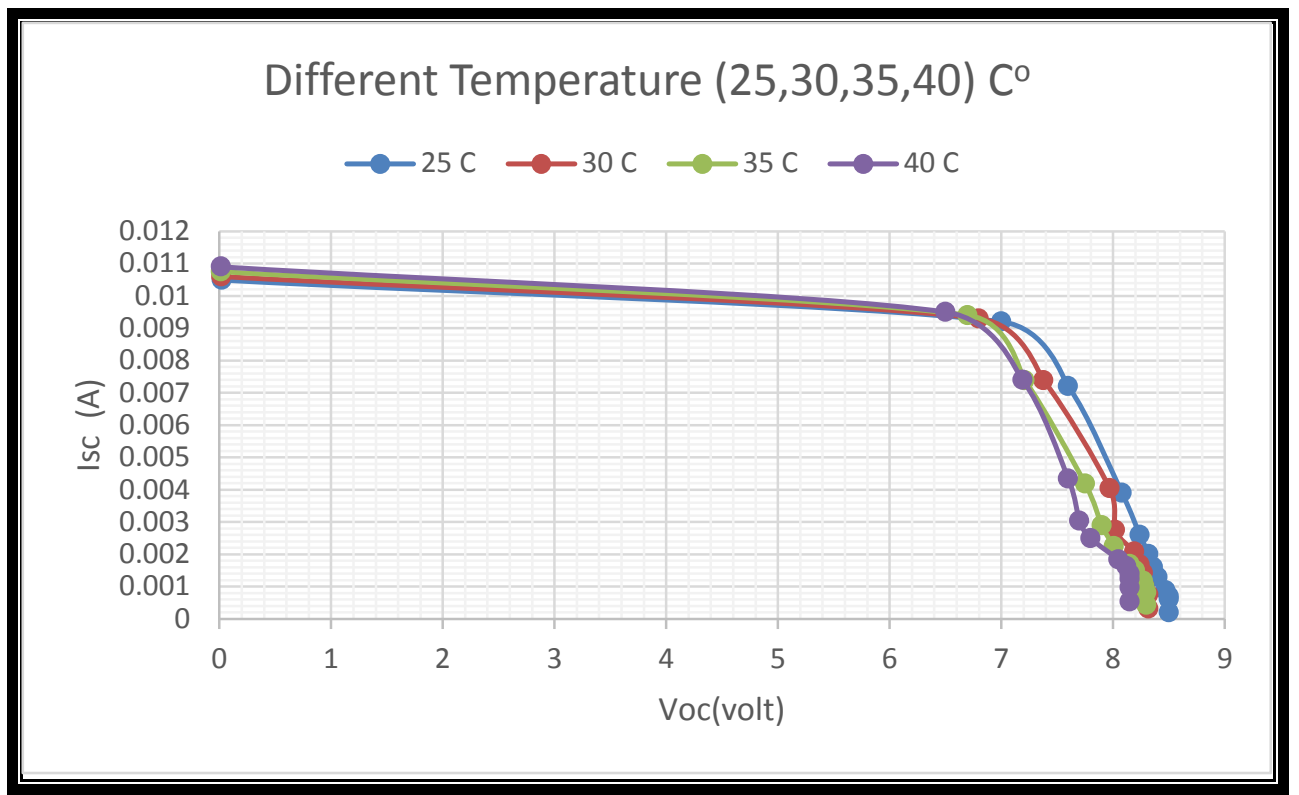

Figure 8. Output I-V characteristics of the PV module with different temperatures (25-30-35-40) $\mathrm{C}^{\mathrm{O}}$

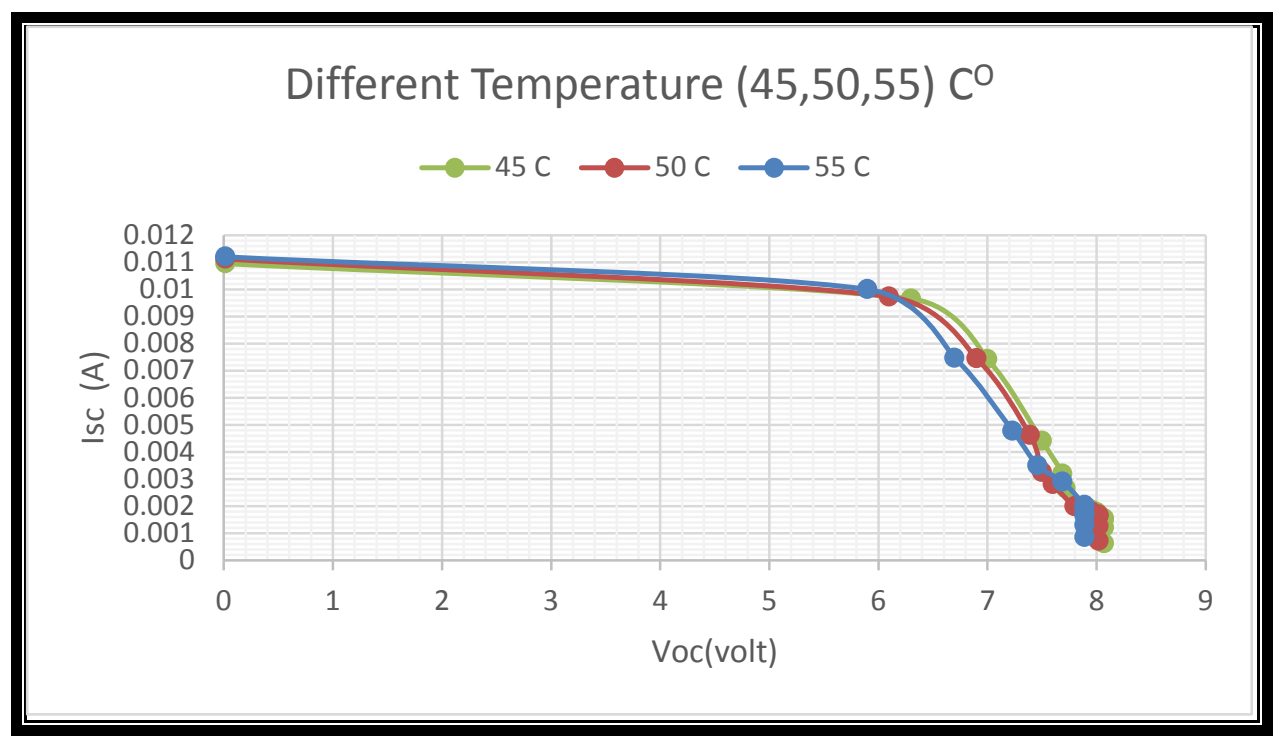

Figure 9. Output I-V characteristics of the PV module with different temperatures (45-50-55) $\mathrm{C}^{\mathrm{O}}$ 


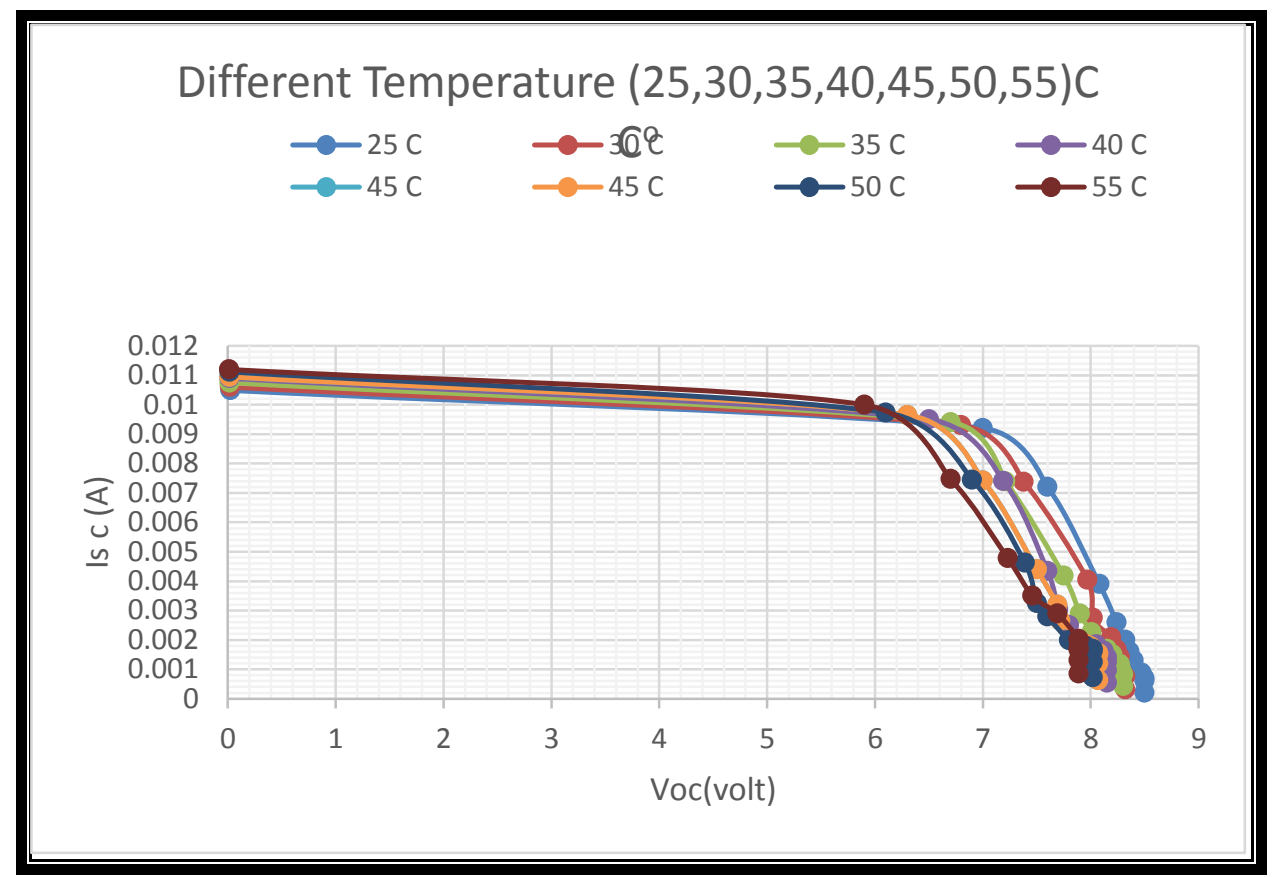

Figure 10. Output I-V characteristics of the PV module with different temperatures (25-30-35-40-45-50-55) $\mathrm{C}^{\mathrm{O}}$

Table 9. Out put parameter of solar cell for different temperature

\begin{tabular}{cccccccc}
\hline $\mathrm{T}\left(\mathrm{C}^{\mathrm{O}}\right)$ & $V_{o c}(\mathrm{~V})$ & $\mathrm{Is}(\mathrm{m} \mathrm{A})$ & $\mathrm{Vm}(\mathrm{V})$ & $\mathrm{Im}(\mathrm{mA})$ & $\mathrm{Pm}($ watt $)$ & FF & Efficiency \\
\hline 25 & 8.5 & 0.01049 & 6.3 & 0.01 & 0.063 & 0.633 & 0.0285 \\
\hline 30 & 8.32 & 0.0106 & 6.1 & 0.0101 & 0.0616 & 0.631 & 0.0279 \\
\hline 35 & 8.31 & 0.01075 & 6 & 0.0102 & 0.0612 & 0.616 & 0.0276 \\
\hline 40 & 8.15 & 0.0109 & 5.8 & 0.0103 & 0.0597 & 0.616 & 0.027 \\
\hline 45 & 8.07 & 0.01095 & 5.5 & 0.0104 & 0.0572 & 0.614 & 0.0259 \\
\hline 50 & 8.02 & 0.01112 & 5.3 & 0.0106 & 0.0562 & 0.604 & 0.0254 \\
\hline 55 & 7.89 & 0.01125 & 5.2 & 0.0107 & 0.0556 & 0.598 & 0.0252 \\
\hline
\end{tabular}

\section{Discussion}

Table 9 shows that the open circuit voltage $V_{o c}$ decreases considerably upon increasing temperature. This may be related to the increase of ions migration upon increasing temperature. These ions which are in the depletion layer are responsible for the open circuit voltage. The decrease of their number in the depletion layer deceases the open circuit voltage. This may explain the decrease of maximum voltage $V_{m}$ as well. However, increasing temperature increases the short circuit and maximum current. This may be attributed to the fact that increasing temperature increases the rate of atomic collisions which increases the rate of liberated electrons. The fill factor FF and the efficiency $\eta$ decreases upon increasing temperature. This indicates that the effect of voltage decrease is more significant than the effect of current increase.

\section{Conclusions}

Increasing temperature of the solar cell decreases the open circuit and the maximum voltage as well as the fill factor and efficiency. However the temperature increase decreases the short circuit and maximum current.

\section{References}

Braun, A., Katz, E. A., \& Gordon, J. M. (2012). Basic aspects of the temperature coefficients of concentrator solar cell performance parameters. Progress in Photovoltaics: Research and Applications. https://doi.org/10.1002/pip.2210

Brown, S., \& Green, M. A. (2002). Detailed balance limit for the series constrained two terminal tandem solar 
cell. Physica E: Low-dimensional Systems and Nanostructures. https://doi.org/10.1016/S1386-9477(02)00364-8

Fang, J., Su, L., Wu, J., Shen, Y., \&. Lu, Z. (2007). The highest power conversion efficiencies. New J. Chem.

Green, M. A. (2006). Third generation photovoltaics: advanced solar energy conversion. Birkhäuser.

Green, M. A. (2011). Crystalline and thin-film silicon solar cells: state of the art and future potential. Solar Energy.

Kamat, P. V., et al.. (2010). Nanoparticles, in Handbook of Nanostructured Materials and Nanotechnology. Academic Press: New York.

Li, B., Wang, L., Kang, B., \& Qiu, Y. (2006). Solar Energy Materials and Solar Cells. Wiley-VCH.

Markoff. (2007). John "Nanosolar". New York.

Sattlerm, D. (2011). Handbook of Nanophysics. CRC. New York. https://doi.org/10.1201/9781420075519

Schmidt, W., Woesten, B., \& Kalejs, J. P. (2002). Manufacturing technology for ribbon silicon (EFG) wafers and solar cells. Progress in Photovoltaics. https://doi.org/10.1002/pip.411

Shockley, W., \& Queisser, H. J. (1961). Low Power of Efficiency of P-N Junction Solar Cells. Journal of Applied Physics. https://doi.org/10.1063/1.1736034

Sze, S. M. (1985). Semiconductor Devices: Physics and Technology. Wiley, New York.

Vidal, J. (2007). Solar energy 'revolution' brings green power closer. London: The Guardian.

Würfel, P. (2005). Physics of Solar Cells - From Principles of New Concepts. Wiley-VCH. https://doi.org/10.1002/9783527618545

\section{Copyrights}

Copyright for this article is retained by the author(s), with first publication rights granted to the journal.

This is an open-access article distributed under the terms and conditions of the Creative Commons Attribution license (http://creativecommons.org/licenses/by/4.0/). 